\title{
Synthesis and antibacterial profiles of targeted triclosan derivatives
}

Article

Accepted Version

Creative Commons: Attribution-Noncommercial-No Derivative Works 4.0

Howse, G. L., Bovill, R. A., Stephens, P. J. and Osborn, H. M. I. (2019) Synthesis and antibacterial profiles of targeted triclosan derivatives. European Journal of Medicinal

Chemistry, 162. pp. 51-58. ISSN 0223-5234 doi:

https://doi.org/10.1016/j.ejmech.2018.10.053 Available at https://centaur.reading.ac.uk/80312/

It is advisable to refer to the publisher's version if you intend to cite from the work. See Guidance on citing.

To link to this article DOI: http://dx.doi.org/10.1016/j.ejmech.2018.10.053

Publisher: Elsevier

All outputs in CentAUR are protected by Intellectual Property Rights law, including copyright law. Copyright and IPR is retained by the creators or other copyright holders. Terms and conditions for use of this material are defined in the End User Agreement.

\section{www.reading.ac.uk/centaur}

\section{CentAUR}

Central Archive at the University of Reading 
Reading's research outputs online 


\section{Accepted Manuscript}

Synthesis and antibacterial profiles of targeted triclosan derivatives

Gemma L. Howse, Richard A. Bovill, Peter J. Stephens, Helen M.I. Osborn

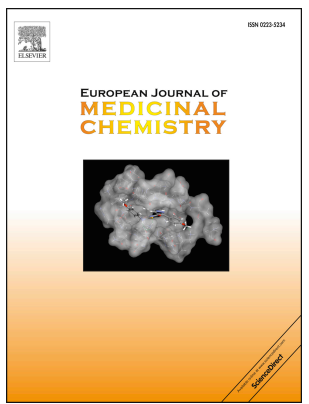

PII:

S0223-5234(18)30923-1

DOI:

https://doi.org/10.1016/j.ejmech.2018.10.053

Reference: EJMECH 10839

To appear in: European Journal of Medicinal Chemistry

Received Date: 5 July 2018

Accepted Date: 22 October 2018

Please cite this article as: G.L. Howse, R.A. Bovill, P.J. Stephens, H.M.I. Osborn, Synthesis and antibacterial profiles of targeted triclosan derivatives, European Journal of Medicinal Chemistry (2018), doi: https://doi.org/10.1016/j.ejmech.2018.10.053.

This is a PDF file of an unedited manuscript that has been accepted for publication. As a service to our customers we are providing this early version of the manuscript. The manuscript will undergo copyediting, typesetting, and review of the resulting proof before it is published in its final form. Please note that during the production process errors may be discovered which could affect the content, and all legal disclaimers that apply to the journal pertain. 


\title{
Synthesis and Antibacterial profiles of Targeted Triclosan Derivatives
}

\author{
Gemma L. Howse, ${ }^{\text {a }}$ Richard A. Bovill, ${ }^{\text {b\# }}$ Peter J. Stephens, ${ }^{\text {b }}$ Helen M. I. Osborn ${ }^{\text {a\# }}$ \\ ${ }^{a}$ Reading School of Pharmacy, University of Reading, Whiteknights, Reading. RG6 6AD. UK \\ ${ }^{\mathrm{b}}$ ThermoFisher Scientific, Wade Road, Basingstoke, Hampshire. RG24 8PW. UK \\ \# To whom correspondence should be addressed. Richard Bovill : Richard.bovill@thermofisher.com; \\ Helen Osborn : h.m.i.osborn@ reading.ac.uk
}

\begin{abstract}
There is an ongoing urgent need for new targeted antibacterial compounds with novel mechanisms of action for the treatment of infections caused by bacteria that are resistant to currently available materials. Since the expression of glycosidase enzymes within bacteria is unequally distributed, glycoside derivatives of antibacterial agents offer potential as targeted prodrugs for bacterial infections. Herein we report the synthesis and characterisation of four $\alpha$-D-glycopyranosides and three $\beta$-D-glycopyranosides of the broad antibacterial agent triclosan, in generally very good synthetic yields, and with excellent purities. Each glycoside was analysed to determine its ability to inhibit the growth of a wide range of Gram-negative and Gram-positive organisms, including many of clinical significance. All of the triclosan glycosides that were synthesized demonstrated antibacterial activity against many of the organisms that were examined. For example, $\beta$-galactoside (3a) and $\alpha$-arabinoside (3c) had MIC values of $0.5 \mu \mathrm{g} / \mathrm{ml}$ for several strains of $S$. aureus and S. haemolyticus. The triclosan glycosides were also generally found to be more water soluble and much more selective than the underivatized triclosan, making them ideal both for the targeted inhibition of bacterial growth and as agents for the selective recovery of bacteria from mixed cultures. In the latter case, two Bacillus strains could be identified from various strains of Bacillus and Staphylococcus after inoculation onto Nutrient Agar No. 2 with $0.25 \mu \mathrm{g} / \mathrm{ml}$ triclosan- $\alpha$-D-glucopyranoside (3e). This glucoside may, therefore, be of use for the isolation and identification of the food-poisoning organism Bacillus cereus.
\end{abstract}

Keywords: antibacterial, prodrug, selective recovery

\section{Introduction}

The need for new antibacterial compounds to treat human bacterial infections has never been more important. The introduction of antibiotics into clinical use represented one of the most significant milestones in medicine, and allowed huge advances in areas such as organ transplantation, major surgeries and cancer 
chemotherapy. However, this extensive use, alongside their widespread misuse, has contributed to the spread of antibiotic resistance. Strains of bacteria demonstrating widespread resistance to antibiotics

("Multi-drug-resistant", "Pan-drug-resistant") are being isolated at an alarming rate (1). It is estimated that by 2050, 10 million lives a year and a cumulative 100 trillion USD of economic output are at risk due to the rise of drug-resistant infections. Even today, 700,000 people die of resistant infections every year (2). In a recent WHO study it was found that very few new antibiotics are in the clinical pipeline and most of those are modifications of existing classes to which resistant mechanisms are arising. Very few potential treatment options were identified for those antibiotic-resistant infections posing the greatest threat to health, including drug-resistant tudeculosis which kills around 250,000 people each year (3).

Triclosan (TCS; 5-chloro-2-[2,4-dichlorophenoxy]phenol) (Figure 1) also known as irgasan is a synthetic, non-ionic, bis-aryl antimicrobial which has been shown to have anti-fungal and anti-viral properties (4-9). It is non-toxic to humans but has a broad-spectrum of activity inhibiting all commonly encountered pathogens. Its mechanism of antibacterial action at higher concentrations is towards the cell wall but at lower concentrations it inhibits fatty acid synthesis at the enoyl-acyl carrier protein reductase (FabI) step (10-13). Fatty acid synthesis is essential in bacteria and inhibition causes disruption of the cell membrane and cell breakdown (14-16).

Whilst triclosan has been extensively used as a disinfectant and has become widely used in many food preparation and household products, its low solubility at physiological $\mathrm{pH}$ has limited its antibacterial usage to topical treatments. Derivatizing the hydroxyl group, which is an essential functional group for antibacterial activity, to form a glycoside would be expected to improve its aqueous solubility and enhance its uptake into bacterial cells via active carbohydrate transport mechanisms (17-19) whilst also limiting its toxicity to those organisms that are able to remove the sugar using the appropriate glycosidase enzyme. Since glycosidases are unevenly distributed throughout bacterial taxa (20-24) these targeted bacterial growth inhibitors would offer the advantage of not disturbing the natural bioflora of the patient. The triclosan glycosides would also be useful as selective agents in bacterial isolation media, hence allowing more easy ideintification of bacterial pathogens in food and clinical samples.

The aim of this investigation was therefore to synthesise a range of novel $\alpha$ - and $\beta$-linked triclosan glycosides with enhanced aqueous solubility and targeted antibacterial properties compared with triclosan.

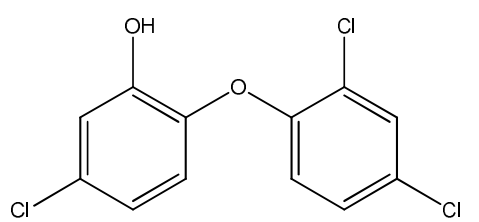

(1)

Figure 1 


\section{Results and Discussion}

Triclosan- $\beta$-D-galactopyranoside (3a), $\beta$-D-glucopyranoside (3b) and $\alpha$-D-arabinopyranoside (3c) were each synthesized in two steps as summarised in Scheme 1. The first step involved reaction of the bromide donor with triclosan (1) in the presence of $1 \mathrm{M} \mathrm{NaOH}$ (1.06 eq.) to yield, selectively, the desired trans-linked protected glycopyranosides (2a-2c) in generally good yields. These were then deprotected by treatment with $\mathrm{MeOH}$ and catalytic $\mathrm{K}_{2} \mathrm{CO}_{3}(0.1$ eq.) to afford the required triclosan glycosides (3a-3c) in very good to excellent yields (25).

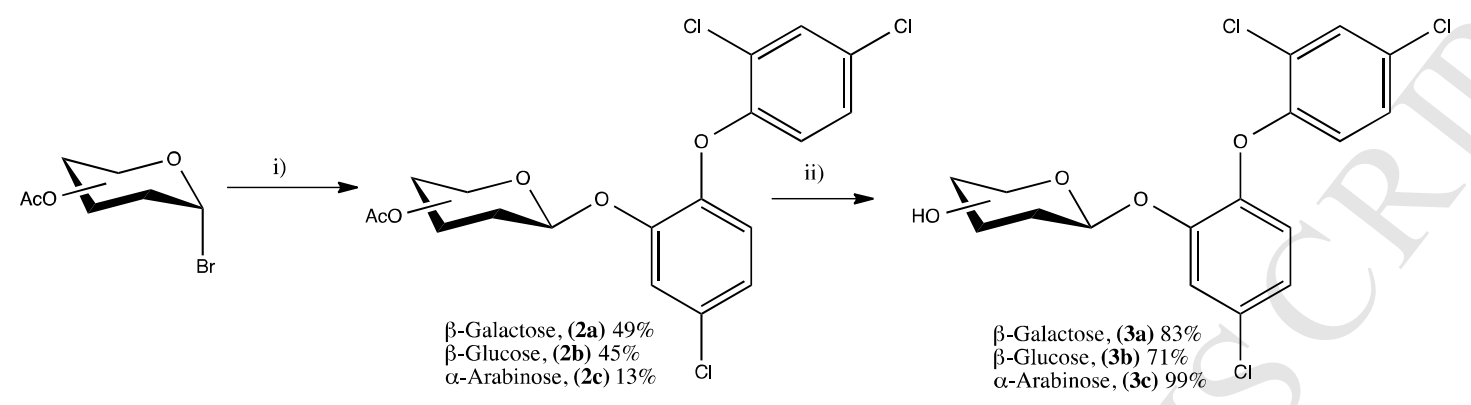

Scheme I. i) $45 \% \mathrm{HBr}$ in $\mathrm{AcOH}, 0{ }^{\circ} \mathrm{C}, 1.5-3 \mathrm{~h}$ : ii) triclosan (1), $1 \mathrm{M} \mathrm{NaOH}, \mathrm{H}_{2} \mathrm{O} /$ acetone, r.t, 18 h: iii) $\mathrm{MeOH}, \mathrm{K}_{2} \mathrm{CO}_{3}$, r.t, 2-17.5 h.

Synthesis of the thermodynamically favoured $\alpha$-galacto, gluco and mannopyranosides, and $\beta$ arabinopyranoside (2d, 2e, 2f, $\mathbf{2 g}$ respectively), was achieved via glycosidation of the acetate donors under thermodynamic conditions. Removal of the acetyl protecting groups was again achieved using catalytic amounts of potassium carbonate ( 0.1 eq.) in the presence of methanol to afford the triclosan glycosides (3d, 3e, 3f, 3g ) in generally excellent yields.
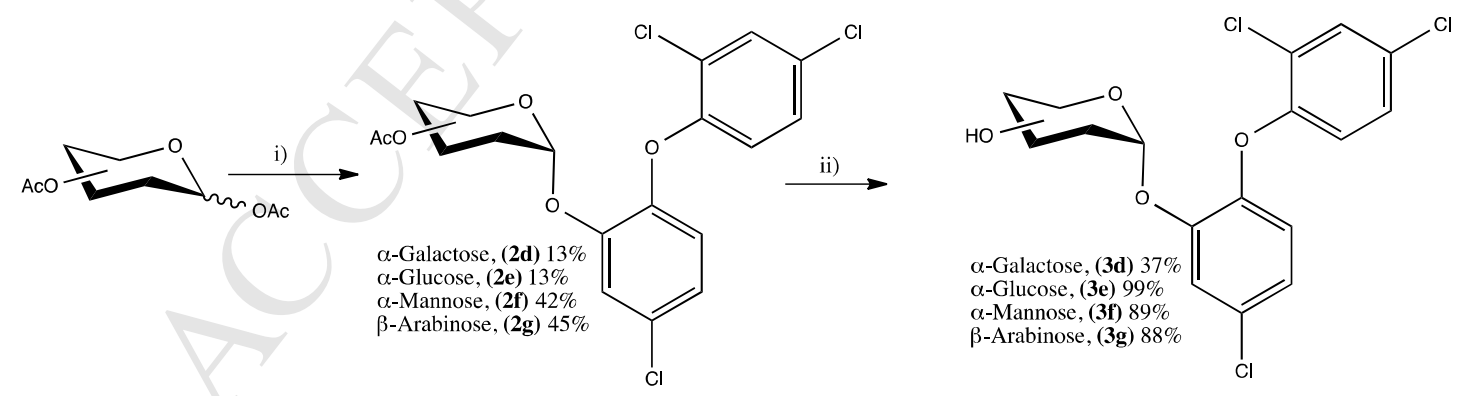

Scheme II. i) triclosan (1), $\mathrm{BF}_{3} . \mathrm{OEt}_{2}, \mathrm{CH}_{2} \mathrm{Cl}_{2}, 0^{\circ} \mathrm{C}$ - r.t, 18 h: ii) $\mathrm{MeOH}, \mathrm{K}_{2} \mathrm{CO}_{3}$, r.t, 3 h.

The structures of the synthesized intermediates and final compounds were confirmed by ${ }^{1} \mathrm{H}$ and ${ }^{13} \mathrm{C}$ NMR spectroscopy and mass spectrometry. In all cases free triclosan and unreacted sugars could not be detected in the final products using HPLC analysis and purities were $\geq 97 \%$. 
The Minimum Inhibitory Concentrations (MICs) for triclosan and its glycosides against a wide range of Gram-negative and Gram-positive bacteria, including many of clinical significance, were generated using the Bioscreen system. Data is summarized in Table 1 (Gram-negative organisms) and Table 2 (Grampositive organisms) below.

Tables 1 and 2 MIC ( $\mu \mathrm{g} / \mathrm{ml})$ of triclosan glycosides for a range of Gram-negative and Grampositive organisms in Nutrient Broth.

\begin{tabular}{|c|c|c|c|c|c|c|c|c|c|}
\hline $\begin{array}{l}\text { Gram-negative } \\
\text { organism }\end{array}$ & $\begin{array}{l}\text { No. of } \\
\text { strains }\end{array}$ & $\begin{array}{c}\text { Triclosan } \\
\text { (1) }\end{array}$ & $\begin{array}{c}\beta \text {-gal } \\
(3 a)\end{array}$ & $\begin{array}{c}\beta \text {-glu } \\
(3 \mathbf{b})\end{array}$ & $\begin{array}{c}\alpha-a r a \\
(3 c)\end{array}$ & $\begin{array}{c}\alpha \text {-gal } \\
(3 d)\end{array}$ & $\begin{array}{l}\alpha \text {-glu } \\
(3 \mathbf{e})\end{array}$ & $\begin{array}{c}\alpha \text {-man } \\
(3 f)\end{array}$ & $\begin{array}{c}\beta \text {-ara } \\
(3 g)\end{array}$ \\
\hline Aer. hydrophila & 1 & 8 & 256 & $>256$ & 128 & $>256$ & 256 & $>256$ & $>256$ \\
\hline Cit. freundii & 1 & 0.5 & 8 & 64 & 8 & 64 & 4 & 64 & 64 \\
\hline Cr. sakazakii & 1 & 0.5 & 8 & 64 & 8 & 128 & 8 & 128 & 128 \\
\hline Ent. aerogenes & 1 & 0.5 & 8 & 64 & 8 & 128 & 8 & 32 & 128 \\
\hline Ent. cloacae & 1 & 0.5 & 0.5 & 16 & 0.5 & 32 & 1 & 8 & 16 \\
\hline E. coli & 8 & $0.1-0.5$ & $0.5-32$ & $8-64$ & $0.5-4$ & $16-64$ & $2-8$ & $4-64$ & $8-32$ \\
\hline E. hermanii & 1 & 0.5 & 2 & 16 & 1 & 32 & 1 & 16 & 32 \\
\hline Hafnia alvei & 1 & 0.1 & 0.5 & 4 & 0.5 & 16 & 1 & 4 & 4 \\
\hline Kleb. aerogenes & 1 & 0.5 & 4 & 32 & 4 & 32 & 2 & 32 & 32 \\
\hline Kleb. & 1 & 0.1 & 0.5 & 0.5 & 0.5 & 1 & 1 & 4 & 4 \\
\hline Pr. mirabilis & 1 & 0.5 & 4 & 16 & 4 & 32 & 2 & 16 & 32 \\
\hline Pr. vulgaris & 1 & 0.5 & 8 & 64 & 16 & 64 & 4 & 32 & 128 \\
\hline Ps. aeruginosa & 1 & 32 & $>256$ & $>256$ & $>256$ & $>256$ & $>256$ & $>256$ & $>256$ \\
\hline Salmonella & 11 & $0.5-1$ & $2-16$ & $16-32$ & $2-8$ & $32-64$ & $2-8$ & $16-64$ & $32-64$ \\
\hline Ser. marcescens & 1 & 64 & $>256$ & $>256$ & $>256$ & $>256$ & $>256$ & $>256$ & $>256$ \\
\hline
\end{tabular}

\begin{tabular}{|l|c|c|c|c|c|c|c|c|c|}
\hline $\begin{array}{l}\text { Gram-positive } \\
\text { organism }\end{array}$ & $\begin{array}{c}\text { No. of } \\
\text { strains }\end{array}$ & $\begin{array}{c}\text { Underiv. } \\
\text { triclosan } \\
(\mathbf{1})\end{array}$ & $\begin{array}{c}\boldsymbol{\beta} \text {-gal } \\
\mathbf{( 3 a})\end{array}$ & $\begin{array}{c}\boldsymbol{\beta} \text {-gluc } \\
(\mathbf{3 b})\end{array}$ & $\begin{array}{c}\boldsymbol{\alpha} \text {-ara } \\
\mathbf{( 3 c})\end{array}$ & $\begin{array}{c}\boldsymbol{\alpha} \text {-gal } \\
(\mathbf{3 d})\end{array}$ & $\begin{array}{c}\boldsymbol{\alpha} \text {-gluc } \\
(\mathbf{3 e})\end{array}$ & $\begin{array}{c}\boldsymbol{\alpha} \text {-man } \\
(\mathbf{3 f})\end{array}$ & $\begin{array}{c}\boldsymbol{\beta} \text {-ara } \\
(\mathbf{3 g})\end{array}$ \\
\hline B. cereus & 1 & 2 & 256 & 256 & 128 & $>256$ & 128 & 256 & 128 \\
\hline B. subtilis & 1 & 1 & 32 & 256 & 32 & 256 & 32 & 128 & 128 \\
\hline Entero. faecalis & 1 & 8 & 128 & 16 & 128 & $>256$ & 128 & 256 & 256 \\
\hline Entero. faecium & 1 & 4 & $>256$ & $>256$ & 256 & $>256$ & 256 & 256 & 256 \\
\hline S. aureus & 8 & 0.01 & 0.5 & $4-8$ & 0.5 & $8-16$ & 1 & $2-8$ & $4-8$ \\
\hline S. epidermidis & 3 & 0.01 & 0.5 & $8-16$ & 0.5 & $8-32$ & 1 & $4-8$ & $8-16$ \\
\hline S. haemolyticus & 1 & 0.01 & 0.5 & 16 & 0.5 & 16 & 1 & 8 & 128 \\
\hline S. saprophyticus & 1 & 0.01 & 8 & 64 & 8 & 64 & 4 & 32 & 64 \\
\hline Str. agalactiae & 1 & 4 & 256 & 256 & 128 & $>256$ & 128 & 128 & 128 \\
\hline Str. pneumoniae & 1 & 1 & 128 & 128 & 64 & 128 & 32 & 64 & 64 \\
\hline
\end{tabular}




\begin{tabular}{|l|c|c|c|c|c|c|c|c|c|}
\hline Str. pyogenes & 1 & 1 & 128 & 32 & 16 & 256 & 32 & 32 & 32 \\
\hline Str. viridans & 1 & 4 & 256 & 256 & 128 & $>256$ & 128 & 128 & 128 \\
\hline
\end{tabular}

From Tables 1 and 2 it can be seen that all of the triclosan glycosides that were synthesized demonstrated antibacterial activity against many of the organisms that were examined. In particular, the $\alpha$ arabinoside (3c) and $\beta$-galactoside (3a) both had MICs of $0.5 \mu \mathrm{g} / \mathrm{ml}$ for several organisms including the pathogenic staphylococcal species $S$. aureus and S. haemolyticus. It is well recognised that Methicillin Resistant Staphylococcus aureus (MRSA) can be difficult to treat and often last resort compounds, that may have toxic side-effects, are therefore used $(26,27)$. That $S$. aureus was one of the most sensitive organisms to the triclosan glycosides is therefore particularly significant from a clinical perspective. Moreover, although various resistance mechanisms are involved for bacteria, resistance in MRSA is mainly due to the production of high levels of $\beta$-lactamase $(28,29)$. Currently, drugs with toxic side-effects are often used (30-32) and hence antibiotics such as those described herein that have a different mode of activity are likely to be particularly valuable.

From Tables 1 and 2 it can also be seen that in contrast to the broad toxicity exhibited by the parent triclosan, the toxicities of the triclosan glycosides varied considerably according to the organism. As an example, the MIC for triclosan was $0.5 \mu \mathrm{g} / \mathrm{ml}$ for eight Gram-negative organisms but MICs for the $\alpha$ arabinoside (3c) for these organisms was from 0.5 to $16 \mu \mathrm{g} / \mathrm{ml}$. This presumably is a reflection of differences in glycosidase activity and/ or transport rates of the arabinoside into the cell, and reinforces the hypothesis that derivatisation of triclosan as glycosides is a useful strategy for enhancing selectivity. Moreover, since the solubility of the triclosan glycosides in growth media and buffers at physiological $\mathrm{pH}$ is much improved compared to underivatised triclosan, which is reflected in the calculated cLogP values for the hexose glycosides of 3.02 compared to 4.80 for triclosan (33), it should be possible to use the $\beta$ galactoside (3a) and the $\alpha$-arabinoside (3c) in peroral and parenteral treatments of MRSA infections rather than only in topical applications, as is the current case for triclosan.

Generally if an organism was resistant to free triclosan it was also resistant to glycosides formed from it, indicating that any resistance is probably due to rapid efflux of triclosan, or its inability to cause disruption to fatty acid biosynthesis rather than poor transport into the cell. Thus, strains of Aeromonas hydrophila, Bacillus cereus, Enterococcus faecium, Ps. aeruginosa, S. marcescens, Streptococcus agalactiae and Streptococcus viridans all demonstrated MIC of 2 or greater for triclosan and 128 or greater for the glycosides. An exception was Enterococcus faecalis with a MIC of $16 \mu \mathrm{g} / \mathrm{ml}$ for the $\beta$-glucoside (3b); only one doubling dilution higher than that for free triclosan.

As the activities of the triclosan glycosides were much more bacterial selective than the underivatized triclosan, this also demonstrates their excellent potential for enriching food or clinical 
specimens for pathogens prior to instrumental, moleular or traditional means of identification. For example, the results in Table 2 demonstrate that the addition of triclosan $\alpha$-arabinoside $(\mathbf{3 c})$ in selective enrichment broth at $1.0 \mu \mathrm{g} / \mathrm{ml}$ would allow recovery of Salmonellae but inhibit the growth of many organisms that outgrow it such as strains of Enterobacter cloacae, Escherichia hermanii, Escherichia coli, Hafnia alvei, Klebsiella pneumoniae and Staphylococcus. Triclosan $\alpha$-mannoside (3f) at $64 \mu \mathrm{g} / \mathrm{ml}$ also demonstrated inhibition profiles that would be particularly useful for the selective recovery of Cronobacter sakazakii which is of particular concern when present in infant formula milk $(34,35)$. To determine whether such differences in toxicity of the triclosan glycosides could indeed be used in selective isolation plates as well as in broth cultures, MIC values were also determined in Nutrient Agar. Pleasingly, results were essentially the same as those obtained in broth (data not shown). As an example, to demonstrate the effectiveness of triclosan glycosides in isolation plates, recovery of Bacillus cereus in the presence of strains of staphylococci was investigated. Bacillus cereus is an important foodborne pathogen in humans causing severe nausea, vomiting, and diarrhoea (36). It is often present in samples with large numbers of other organisms and so can be difficult to isolate. PEMBA medium containing polymyxin B and cycloheximide with egg yolk precipitation as a presumptive identification is usually used (37). The Bacillus and Staphylococcus strains were inoculated onto Nutrient Agar plates with and without $8 \mu \mathrm{g} / \mathrm{ml}$ triclosan- $\alpha$-Dglucopyranoside (3e). Although all strains grew well on Nutrient Agar only the Bacillus cereus strain could be recovered on plates containing the inhibitor (Figure 2) and its growth was not affected by free triclosan that may have been released from dead staphylocococcal cells; presumably amounts were too low or did not permeate through the agar.
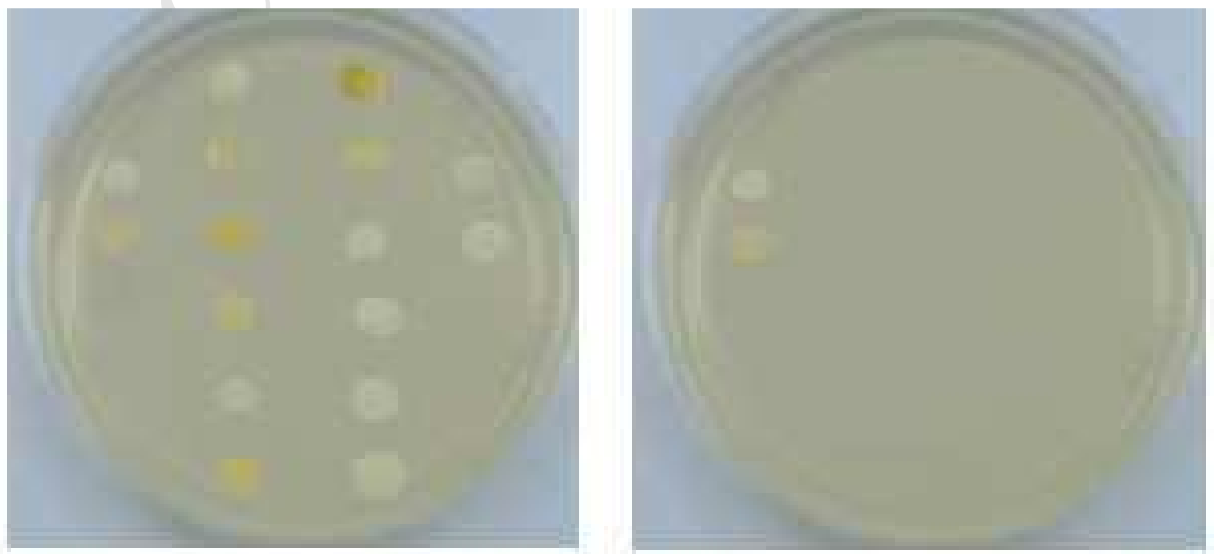

Figure 2. Nutrient agar plates inoculated with strains of Bacillus and Staphylococcus. Left, without and right with $8 \mu \mathrm{g} / \mathrm{ml}$ triclosan- $\alpha$-D-glucopyranoside (3e). Only the 2 Bacillus strains could be recovered on plates containing the inhibitor. 


\section{Conclusions}

Chemical derivatization of the antibacterial agent triclosan was optimised to afford four novel triclosan- $\alpha$-D-glycopyranosides and three novel triclosan- $\beta$-D-glycopyranosides in generally very good yields, and excellent purities. The abilities of the glycosides to inhibit the growth of a broad range of grampositive and gram-negative bacterial organsisms, including many of clinical and industrial relevance, were probed and many were shown to be potent, selective, antibacterial agents. For example, $\beta$-galactoside (3a) and $\alpha$-arabinoside (3c) had MIC values of $0.5 \mu \mathrm{g} / \mathrm{ml}$ for several strains of $S$. aureus and $S$. haemolyticus. Since Methicillin Resistant Staphylococcus aureus can be difficult to treat, and last resort compounds that may have toxic side-effects are often used, this is a significant advance. In addition, since antibacterial resistance in many cases is due to the production of high levels of $\beta$-lactamase, antibiotics with a different mode of activity such as those described herein are highly beneficial. Moreoever, as the glycoside derivatives prepared herein have increased aqueuous solubilities compared with free triclosan, as demonstrated by calculated $\log \mathrm{P}$ values, this now provides opportunities for triclosan to be used perorally for the treatment of systemic infections.

Since the novel glycosides were designed to be hydrolysed to afford triclosan in a bacteria dependent manner, based on the glycosidase profiles of the bacteria, their application for the selective recovery of bacteria from mixed bacterial populations was also explored. The activity of the triclosan glycosides was indeed generally found to be much more selective than the underivatized triclosan, and this was clearly demonstrated when considering the profiles of triclosan $\alpha$-arabinoside (3c) and triclosan $\alpha$-mannoside (3f). For the former, inclusion in selective recovery media at $1.0 \mu \mathrm{g} / \mathrm{ml}$ would allow recovery of Salmonella by inhibition of the growth of many of organisms that compete with Salmonella, such as strains of Enterobacter cloacae, Escherichia hermanii, Escherichia coli, Hafnia alvei, Klebsiella pneumoniae and Staphylococcus. Triclosan $\alpha$-mannoside (3f) also demonstrated inhibition profiles that would be particularly useful for selective recovery, and hence identification, of Cronobacter sakazakii which is of particular concern when present in infant formula milk. In general, results from broth cultures were replicated in selective isolation plates that used Nutrient Agar No. 2. This was exemplified by recovery of two Bacillus strains from various strains of Bacillus and Staphylococcus after inoculation onto NA2 with $0.25 \mu \mathrm{g} / \mathrm{ml}$ triclosan- $\alpha$-Dglucopyranoside (3e). This glucoside is, therefore, of use for the isolation of the food-poisoning organism Bacillus cereus.

Taken together, these results therefore demonstrate that glycoside derivatives of triclosan offer considerable advantages as antibacterial agents compared with triclosan itself, specifically enhanced aqueous solubilities, targeted antibacterial profiles, and a mechanism of action that is complementary with those of existing antibacterial agents. These features have also allowed additional impact to be realised through the selective recovery of bacteria from mixed bacterial populations. 


\section{Acknowledgements}

We would like to express our gratitude to the BBRSC (BB/E527812/1) and Thermo Fisher Scientific for their assistance in providing funding for Gemma Howse

\section{Materials and methods}

Analytical

High Performance Liquid Chromatography (Agilent 1100 series) was used to determine the purity of the synthesised triclosan- $\alpha / \beta$-D-glycopyranosides. A Primsep-B column (weak anion exchange, Hichrom, UK) was used and eluted with $0.1 \%$ formic acid and acetonitrile with a flow rate of $1.5 \mathrm{ml} / \mathrm{min}$. Detection of triclosan (1) and triclosan- $\alpha / \beta$-D-glycopyranosides was determined to be optimal at $275 \mathrm{~nm}$. Calibration curves of both triclosan (1) and the triclosan- $\alpha / \beta$-D-glycopyranosides (dissolved in $\mathrm{H}_{2} \mathrm{O}$ : Acetonitrile, 1:1) were constructed using a concentration range of $7.8 \mu \mathrm{g} / \mathrm{ml}$ to $1000 \mu \mathrm{g} / \mathrm{ml}$ and used to determine the concentration of any triclosan (1) impurity.

NMR spectra were recorded on a Bruker DPX $400 \mathrm{MHz}$ instrument running ICON NMR 2.1 under TOPSPIN 1.3 at the University of Reading (Reading, UK). NMR spectra were analysed using MestreNova v.8.1.4-12489 software (Mestrelab, Santiago de Compostela, Spain). Samples were analysed in either deuterated chloroform $\left(\mathrm{CDCl}_{3}\right)$ or dimethyl sulfoxide (DMSO-d6). Chemical shifts are quoted in parts per million using the abbreviations: s, singlet, d, doublet, at, apparent triplet, as, apparent singlet m, multiplet. All coupling constants are quoted to the nearest $0.5 \mathrm{~Hz}$.

\section{Synthesis (25)}

\section{General procedure A: Glycosylation with $1 \mathrm{M}$ NaOH}

Triclosan (1) (1.06 eq.) was suspended in water (10.4 ml per mmol), $1 \mathrm{M} \mathrm{NaOH} \mathrm{(1.06} \mathrm{eq)} \mathrm{was} \mathrm{then} \mathrm{added.}$ To this was added acetone $(5.8 \mathrm{ml}$ per mmol). Separately, acetobromo-derivative (1 eq.) was dissolved in acetone $(6.2 \mathrm{ml}$ per $\mathrm{mmol})$. This solution was then added in one portion to the stirred solution of triclosan and sodium hydroxide and then stirred at room temperature for 18 hours. The reaction was then extracted with $\mathrm{CH}_{2} \mathrm{Cl}_{2}$, dried $\left(\mathrm{MgSO}_{4}\right)$, and concentrated in vacuo. The crude product was then purified by column chromatography (eluent 3:2 hexane/ethyl acetate).

Synthesis

of

$O$-(2,3,4,6-tetra- $O$-acetyl- $\beta$-D-galactopyranosyl)-5-chloro-2-(2,4-

dichlorophenoxy)phenol (2a). Following general procedure A: Triclosan (1) (1.01 g, $3.5 \mathrm{mmol})$ was reacted with acetobromogalactose $(1.36 \mathrm{~g}, 3.3 \mathrm{mmol})$ to yield $(\mathbf{2 a})$ as a clear oil $(1 \mathrm{~g}, 49 \%)$. $[\alpha]_{\mathrm{D}}{ }^{20^{\circ} \mathrm{C}}-5.1(c$ 13.9, $\mathrm{CHCl}_{3}$ ). ${ }^{1} \mathrm{H} \mathrm{NMR}\left(400 \mathrm{MHz}, \mathrm{CDCl}_{3}\right.$ ), 1.79 (3H, s, OAc), 1.90 (3H, s, OAc), 2.02 (3H, s, OAc), 2.09 (3H, s, OAc), 3.61-4.39 (3H, m, H5, H6', H6), 4.96-5.04 (2H, m, H1, H3), 5.31 (1H, dd, J 10.5, 8.0 Hz, H2), $5.36(1 \mathrm{H}, \mathrm{dd}, J 3.5,1.0 \mathrm{~Hz}, \mathrm{H} 4), 6.64(1 \mathrm{H}, \mathrm{d}, J 9.0 \mathrm{~Hz}, \mathrm{H} 18), 6.74(1 \mathrm{H}, \mathrm{d}, J 8.5 \mathrm{~Hz}, \mathrm{H} 9), 6.96$ (1H, dd, $J$ 8.5, 
$2.5 \mathrm{~Hz}, \mathrm{H} 10), 7.07$ (1H, dd, J 9.0, $2.5 \mathrm{~Hz}, \mathrm{H} 17), 7.22$ (1H, d, J 2.5 Hz, H12), 7.37 (1H, d, J 2.5 Hz, H15).

${ }^{13} \mathrm{C}$ NMR (100 MHz, $\mathrm{CDCl}_{3}$ ), 20.3 (OAc), 20.5 (OAc), 20.6 (OAc), 20.6 (OAc), 61.7 (C6), 66.9 (C4), 68.2 (C2), 70.6 (C3), 71.4 (C5), 100.1 (C1), 119.0 (C18), 119.8 (C12), 121.1 (C9), 124.2 (C10), 125.1 (ArQ), 127.9 (C17), 128.6 (ArQ), 129.8 (ArQ), 130.4 (C15), 144.4 (ArQ), 148.1 (ArQ), 151.4 (ArQ)168.9 (OAc), 169.9 (OAc), 170.1 (OAc), 170.4 (OAc). IR $v_{\max } / \mathrm{cm}^{-1}$ (thin film), 3085 (C-H arene), 2971 (C-H), 1757 $(\mathrm{C}=\mathrm{O}), 1589$ (C=C), 1367 (C-O), 1064 (C-C), 736 (C-C), 643 (C-Cl). FTMS (ESI, M+Na), 641.0338 $\mathrm{C}_{26} \mathrm{H}_{25} \mathrm{O}_{11} \mathrm{C}_{13} \mathrm{Na}$, req. 641.0355 .

\section{Synthesis of $O$-(2,3,4,6-tetra- $O$-acetyl- $\beta$-D-glucopyranosyl)-5-chloro-2-(2,4-dichlorophenoxy)phenol}

(2b). Following general procedure A: Triclosan (1) $(1.1 \mathrm{~g}, 3.8 \mathrm{mmol})$ was reacted with acetobromoglucose $(1.47 \mathrm{~g}, 3.6 \mathrm{mmol})$ to yield $(\mathbf{2 b})$ as a clear oil $(1 \mathrm{~g}, 45 \%) .[\alpha]_{\mathrm{D}}{ }^{20^{\circ} \mathrm{C}} \quad-6.26\left(c 4.6, \mathrm{CHCl}_{3}\right) .{ }^{1} \mathrm{H} \mathrm{NMR}(400$ $\mathrm{MHz}, \mathrm{CDCl}_{3}$ ), 1.86 (3H, s, OAc), 2.00 (3H, s, OAc), 2.05 (3H, s, OAc), 2.12 (3H, s, OAc), 3.92-3.97 (1H, m, H5), 4.20-4.24 (2H, m, H6', H6), 5.10 (1H, app. t. J 8.0 Hz, H4), 5.13-5.18 (2H, m, H1, H2/3), 5.24-5.35 (1H, m, H2/3), $6.71(1 \mathrm{H}, \mathrm{d}, J 9.0 \mathrm{~Hz}, \mathrm{H} 18), 6.86$ (1H, d, J 8.5 Hz, H9), 7.05 (1H, dd, J 8.5, $2.5 \mathrm{~Hz}, \mathrm{H} 10)$, $7.14(1 \mathrm{H}, \mathrm{dd}, J$ 9.0, $2.5 \mathrm{~Hz}, \mathrm{H} 17), 7.28(1 \mathrm{H}, \mathrm{d}, J 2.5 \mathrm{~Hz}, \mathrm{H} 12), 7.44(1 \mathrm{H}, \mathrm{d}, J 2.5 \mathrm{~Hz}, \mathrm{H} 15) .{ }^{13} \mathrm{C}$ NMR $(100$ MHz, $\mathrm{CDCl}_{3}$ ), 20.2 (OAc), 20.4 (OAc), 20.4 OAc), 20.6 (OAc), 62.0 (C6), 68.25 (C4), 70.7 (C2/3), 72.2 (C5), 72.4 (C2/3), 99.26 (C1), 118.7 (C18), 119.0 (C12), 121.4 (C9), 124.1 (C10), 124.9 (ArQ), 127.8 (C17), 128.5 (ArQ), 129.8 (ArQ), 130.3 (C15), 144.0 (ArQ), 148.1 (ArQ), 151.0 (ArQ), 168.8 (OAc), 169.3 (OAc), 169.9 (OAc), 170.4 (OAc). IR $v_{\max } / \mathrm{cm}^{-1}$ (thin film), 3069 (C-H arene), $2961(\mathrm{C}-\mathrm{H}), 1746(\mathrm{C}=\mathrm{O})$, $1594(\mathrm{C}=\mathrm{C}), 1364(\mathrm{C}-\mathrm{O}), 731(\mathrm{C}-\mathrm{C}), 651(\mathrm{C}-\mathrm{Cl})$. FTMS (ESI, M+Na), $641.0334 \mathrm{C}_{26} \mathrm{H}_{25} \mathrm{O}_{11} \mathrm{Cl}_{3} \mathrm{Na}$, req. 641.0355 .

\section{Synthesis of $O$-(2,3,4-tri- $O$-acetyl- $\alpha$-D-arabinopyranosyl)-5-chloro-2-(2,4-dichlorophenoxy)phenol}

(2c). Following general procedure A: Triclosan (1) $(8.1 \mathrm{~g}, 28 \mathrm{mmol})$ was reacted with acetobromoarabinose $(9.03 \mathrm{~g}, 26 \mathrm{mmol})$ to yield $(\mathbf{2 c})$ as a clear oil $(1.78 \mathrm{~g}, 13 \%) .[\alpha]_{\mathrm{D}}{ }^{20^{\circ} \mathrm{C}}+11\left(c 0.9, \mathrm{CHCl}_{3}\right) .{ }^{1} \mathrm{H}$ NMR $(400$ $\mathrm{MHz}, \mathrm{CDCl}_{3}$ ), 1.95 (3H, s, OAc), 1.99 (3H, s, OAc), 2.05 (3H, s, OAc), 3.72 (1H, dd, J 13.0, 2.5 Hz, H5'), 4.09-4.15 (1H, m, H5), 5.10-5.12 (2H, m, H1, H2/H3), 5.27-5.31 (2H, m, H2/H3, H4), 6.73 (1H, d, J 9.0 Hz, H18), 6.79 (1H, d, J 8.5 Hz, H9), 7.03 (1H, dd, J 8.5, 2.5 Hz, H10), 7.16 (1H, dd, J 9.0, 2.5 Hz, H17), 7.26 $(1 \mathrm{H}, \mathrm{d}, J 2.5 \mathrm{~Hz}, \mathrm{H} 12), 7.46(1 \mathrm{H}, \mathrm{d}, J 2.5 \mathrm{~Hz}, \mathrm{H} 15) .{ }^{13} \mathrm{C} \mathrm{NMR}\left(100 \mathrm{MHz}, \mathrm{CDCl}_{3}\right), 20.5$ (OAc), 20.6 (OAc), 20.9 (OAc), 21.1 (OAc), 60.4 (C5), 66.7 (C2/C3/C4), 68.7 (C2/C3/C4), 69.2 (C2/C3/C4), 99.4 (C1), 119.2 (C18), 120.0 (C12), 121.0 (C9), 124.2 (C10), 128.0 (C17), 130.5 (C15). IR $v_{\max } / \mathrm{cm}^{-1}$ (thin film), 1748 $(\mathrm{C}=\mathrm{O}), 1636(\mathrm{C}=\mathrm{C}), 1474(\mathrm{C}=\mathrm{C}), 1371(\mathrm{C}-\mathrm{O}), 1227(\mathrm{C}-\mathrm{O})$. FTMS (+ p APCI, M+Na) 569.0141 $\mathrm{C}_{23} \mathrm{H}_{21} \mathrm{O}_{9} \mathrm{Cl}_{3} \mathrm{Na}$ req. 569.0143. FTMS (ESI, $\left.\mathrm{M}+\mathrm{Na}\right) 569.0141 \mathrm{C}_{23} \mathrm{H}_{21} \mathrm{O}_{9} \mathrm{Cl}_{3} \mathrm{Na}$ req. 569.0143.

\section{General procedure B: Glycosylation with $\mathbf{B F}_{3} \cdot \mathbf{O E t}_{2}$}

Under argon, the per-O-acetylated carbohydrate ( 1 eq.) was dissolved in anhydrous $\mathrm{CH}_{2} \mathrm{Cl}_{2}$. To this was added triclosan (1) (1.06 eq.). The reaction was then cooled to $0{ }^{\circ} \mathrm{C}$ and $\mathrm{BF}_{3} \cdot \mathrm{OEt}_{2}$ (3 eq.) was then added. The reaction was then allowed to warm to room temperature and stirred for 18 hours. Water was then added to quench the reaction, which was then stirred for a further 15 minutes. The reaction was then diluted with 
$\mathrm{CH}_{2} \mathrm{Cl}_{2}$, washed with water, brine, dried $\left(\mathrm{MgSO}_{4}\right)$, filtered and concentrated in vacuo. The crude product was then purified by column chromatography (eluent 3:2 hexane/ethyl acetate) to yield the desired product.

Synthesis of $\quad O$-(2,3,4,6-tetra- $O$-acetyl- $\alpha$-D-galactopyranosyl)-5-chloro-2-(2,4dichlorophenoxy)phenol (2d). Following general procedure B: 1,2,3,4,6-Penta- $O$-acetyl- $\beta$-Dgalactopyranoside $(2 \mathrm{~g}, 5.12 \mathrm{mmol})$ was reacted with triclosan (1) $(1.57 \mathrm{~g}, 5.43 \mathrm{mmol})$ in the presence of $\mathrm{BF}_{3} . \mathrm{OEt}_{2}(1.9 \mathrm{ml}, 15.4 \mathrm{mmol})$ to yield $(\mathbf{2 d})$ as a clear oil $(400 \mathrm{mg}, 13 \%)$. $[\alpha]_{\mathrm{D}}{ }^{20^{\circ} \mathrm{C}}+23\left(c 1.1, \mathrm{CHCl}_{3}\right) .{ }^{1} \mathrm{H}$ NMR (400 MHz, CDCl $), 1.91$ (3H, s, OAc), 1.99 (3H, s, OAc), 2.03 (3H, s, OAc), 2.15 (3H, s, OAc), 4.094.14 (2H, m, H6', H6), 4.28 (1H, app.t, J 7.0 Hz, H5), 5.18-5.25 (2H, m, H2, H3), 5.45-5.46 (1H, m, H4), $5.80(1 \mathrm{H}, \mathrm{d}, J 3.0 \mathrm{~Hz}, \mathrm{H} 1), 6.77(1 \mathrm{H}, \mathrm{d}, J 9.0 \mathrm{~Hz}, \mathrm{H} 18), 6.89$ (1H, d, J 8.5 Hz, H9), 7.04 (1H, dd, J 8.5, 2.5 $\mathrm{Hz}, \mathrm{H} 10), 7.17$ (1H, dd, J 9.0, $2.5 \mathrm{~Hz}, \mathrm{H} 17), 7.25$ (1H, d, J $2.5 \mathrm{~Hz}, \mathrm{H} 12), 7.50(1 \mathrm{H}, \mathrm{d}, J 2.5 \mathrm{~Hz}, \mathrm{H} 15) .{ }^{13} \mathrm{C}$ NMR (100 MHz, $\mathrm{CDCl}_{3}$ ), 20.4 (OAc), 20.5 (OAc), 20.5 (OAc), 20.9 (OAc), 61.7 (C6), 67.2 (C2/C3/C4/C5), 67.4 (C2/C3/C4/C5), 67.6 (C2/C3/C4/C5), 67.6 (C2/C3/C4/C5), 95.8 (C1), 119.1 (C18), 119.3 (C12), 121.2 (C9), 123.9 (C10), 125.2 (ArQ), 127.9 (C17), 128.9 (ArQ), 129.8 (ArQ), 130.7 (C15), 144.7 (ArQ), 147.1 (ArQ), 151.6 (ArQ), 169.5 (OAc), 170.0 (OAc), 170.3 (OAc), 170.3 (OAc). IR $v_{\max } / \mathrm{cm}^{-1}$ (oil), $1757(\mathrm{C}=\mathrm{O}), 1472(\mathrm{C}=\mathrm{C}), 1370$ (C-O), 1095 (C-O), $829(\mathrm{C}-\mathrm{H}), 727$ (C-Cl). FTMS (ESI, M+Na) $641.0356 \mathrm{C}_{26} \mathrm{H}_{25} \mathrm{O}_{11} \mathrm{Cl}_{3} \mathrm{Na}$ req. 641.0355 .

Synthesis of $O$-(2,3,4,6-tetra- $O$-acetyl- $\alpha$-D-glucopyranosyl)-5-chloro-2-(2,4-dichlorophenoxy)phenol (2e). Following general procedure B: 1,2,3,4,6-Penta- $O$-acetyl- $\beta$-D-glucopyranside (500 mg, $1.28 \mathrm{mmol}$ ) was reacted with triclosan (1) $(393 \mathrm{mg}, 1.36 \mathrm{mmol})$ in the presence of $\mathrm{BF}_{3} . \mathrm{OEt}_{2}(0.5 \mathrm{ml}, 3.84 \mathrm{mmol})$ to yield (2e) as a clear oil $(103 \mathrm{mg}, 13 \%) .[\alpha]_{\mathrm{D}}{ }^{20^{\circ} \mathrm{C}}+5.3\left(c 0.5, \mathrm{CHCl}_{3}\right) .{ }^{1} \mathrm{H} \mathrm{NMR}\left(400 \mathrm{MHz}, \mathrm{CDCl}_{3}\right) 1.94(3 \mathrm{H}, \mathrm{s}$, OAc), 2.01 (3H, s, OAc), 2.05 (3H, s, OAc), 2.06 (3H, s, OAc), 3.88 (1H, ddd, J 10.0, 5.5, 2.0 Hz, H5), 4.03 $(1 \mathrm{H}, \mathrm{dd}, J$ 12.0, $2.0 \mathrm{~Hz}, \mathrm{H6}$ '), 4.17 (1H, dd, $J$ 12.0, $5.5 \mathrm{~Hz}, \mathrm{H} 6), 4.92(1 \mathrm{H}, \mathrm{dd}, J 10.0,3.5 \mathrm{~Hz}, \mathrm{H} 2), 5.02(1 \mathrm{H}$, dd, $J$ 10.0, $9.5 \mathrm{~Hz}, \mathrm{H} 4), 5.16$ (1H, app.t, $J 9.5 \mathrm{~Hz}, \mathrm{H} 3), 5.73(1 \mathrm{H}, \mathrm{d}, J 3.5 \mathrm{~Hz}, \mathrm{H} 1), 6.71(1 \mathrm{H}, \mathrm{d}, J 9.0 \mathrm{~Hz}$, H18), 6.97 (1H, d, J 8.5 Hz, H9), 7.06 (1H, dd, J 8.5, 2.5 Hz, H10), 7.15 (1H, dd, J 9.0, 2.5 Hz, H17), 7.21 $(1 \mathrm{H}, \mathrm{d}, J 2.5 \mathrm{~Hz}, \mathrm{H} 12), 7.54$ (1H, d, J $2.5 \mathrm{~Hz}, \mathrm{H} 15) .{ }^{13} \mathrm{C} \mathrm{NMR}\left(100 \mathrm{MHz}, \mathrm{CDCl}_{3}\right), 20.5$ (2 x OAc), $20.6(2 \mathrm{x}$ OAc), 61.8 (C6), 68.1 (C4), 68.3 (C5), 69.8 (C3), 70.2 (C2), 94.7 (C1), 118.4 (C12), 118.4 (C18), 121.9 (C9), 123.9 (C10), 127.8 (C17), 131.1 (C15). IR v $v_{\max } / \mathrm{cm}^{-1}$ (oil), 1746 (C=O), 1599 (C=C), 1409 (C=C), 1248 (C-O), 1023 (C-O), 849 (C-H), 812 (C-H), 757 (C-Cl). FTMS (ESI, M+Na) $641.0356 \mathrm{C}_{26} \mathrm{H}_{25} \mathrm{O}_{11} \mathrm{Cl}_{3} \mathrm{Na}$ req. 641.0355 .

Synthesis

of

$O$-(2,3,4,6-tetra- $O$-acetyl- $\alpha$-D-mannopyranosyl)-5-chloro-2-(2,4-

dichlorophenoxy)phenol (2f). Following general procedure B: 1,2,3,4,6-penta- $O$-acetyl- $\alpha / \beta-D-$ mannopyranoside $(5.0 \mathrm{~g}, 13 \mathrm{mmol})$ was reacted with triclosan (1) $(3.99 \mathrm{~g}, 14 \mathrm{mmol})$ in the presence of $\mathrm{BF}_{3} . \mathrm{OEt}_{2}(4.8 \mathrm{ml}, 39 \mathrm{mmol})$ to yield $(\mathbf{2 f})$ as a clear oil $(3.39 \mathrm{~g}, 42 \%)$. $[\alpha]_{\mathrm{D}}{ }^{20^{\circ} \mathrm{C}}+27.7\left(\mathrm{c} 1.3, \mathrm{CHCl}_{3}\right) .{ }^{1} \mathrm{H}$ NMR (500 MHz, $\mathrm{CDCl}_{3}$ ), 1.98 (3H, s, OAc), 2.06 (3H,s OAc), 2.07 (3H, s, OAc), 2.15 (3H, s, OAc), 3.83 (1H, ddd, $J$ 10.0, 6.5, 2.0 Hz, H5), 4.05 (1H, dd, J 12.0, 2.0 Hz, H6), 4.18 (1H, dd, $J$ 12.0, 6.5 Hz, H6), 4.89 (1H, dd, J $10.03 .5 \mathrm{~Hz}, \mathrm{H} 3), 5.18-5.23(2 \mathrm{H}, \mathrm{m}, \mathrm{H} 2, \mathrm{H} 4), 5.51(1 \mathrm{H}, \mathrm{d}, J 1.8 \mathrm{~Hz}, \mathrm{H} 1), 6.70$ (1H, d, J 9.0 Hz, 
H18), 7.07-7.8 (2H, m. H9, H10), 7.16 (1H, dd, J 9.0, 2.5 Hz, H17), 7.26-7.27 (1H, m, H12), 7.49 (1H, d, J $2.5 \mathrm{~Hz}, \mathrm{H} 15) .{ }^{13} \mathrm{C}$ NMR (126 MHz, $\mathrm{CHCl}_{3}$ ), 20.3 (OAc), 20.4 (OAc), 20.5 (OAc), 20.5 (OAc), 62.0 (C6), 65.5 (C2/C4), 68.2 (C3), 68.6 (C2/C4), 69.3 (C5), 95.9 (C1), 117.5 (C18/C12), 117.9 (C18/C12), 122.4 (C9/C10), 123.6 (C9/C10), 124.4 (ArQ), 127.7 (C17), 128.1 (ArQ), 130.2 (ArQ), 130.8 (C15), 143.6 (ArQ), 146.5 (ArQ), 152.0 (ArQ), 169.0 (OAc), 169.4 (OAc), 169.6 (OAc), 170.2 (OAc). IR $v_{\max } / \mathrm{cm}^{-1}$ (oil), 1746 $(\mathrm{C}=\mathrm{O}), 1595(\mathrm{C}=\mathrm{C}), 1475(\mathrm{C}=\mathrm{C}), 1222(\mathrm{C}-\mathrm{O}), 1045(\mathrm{C}-\mathrm{O}), 829(\mathrm{C}-\mathrm{H}), 822(\mathrm{C}-\mathrm{H}), 812(\mathrm{C}-\mathrm{H}), 608(\mathrm{C}-\mathrm{Cl})$. FTMS (ESI, $\mathrm{M}+\mathrm{Na}) 569.0150 \mathrm{C}_{23} \mathrm{H}_{21} \mathrm{O}_{9} \mathrm{Cl}_{3} \mathrm{Na}$ req. 569.0143.

\section{Synthesis of $O$-(2,3,4-tri- $O$-acetyl- $\beta$-D-arabinopyranosyl)-5-chloro-2-(2,4-dichlorophenoxy)phenol}

(2g). Following general procedure B: 1,2,3,4-tetra- $O$-acetyl- $\alpha / \beta$-D-arabinpyranose/1,2,3,4-tetra- $O$-acetyl$\alpha / \beta$-D-arabinofuranose $(5.26 \mathrm{~g}, 17 \mathrm{mmol})$ was reacted with triclosan (1) $(5.2 \mathrm{~g}, 18 \mathrm{mmol})$ in the presence of

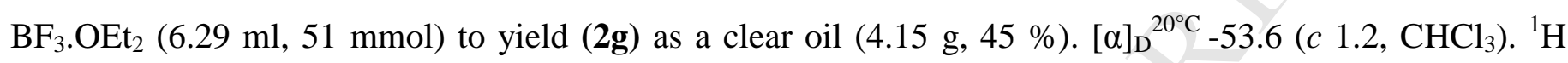
NMR (400 MHz, CDCl $), 1.93$ (3H, s, OAc), 2.01 (3H, s, OAc), 2.13 (3H, s, OAc), 3.74 (1H, dd, J 13.0, 2.0 Hz, H5'), 3.96 (1H, app. d, J 12.5 Hz, H5), 5.17 (1H, dd, J 11.0, 3.5 Hz, H3), 5.25 (1H, dd, J 11.0, 3.5, H2), 5.32-5.33 (1H, m, H4), $5.81(1 \mathrm{H}, \mathrm{d}, J 3.5 \mathrm{~Hz}, \mathrm{H} 1), 6.74(1 \mathrm{H}, \mathrm{d}, J 9.0 \mathrm{~Hz}, \mathrm{H} 18), 6.96$ (1H, d, J 8.5 Hz, H9), $7.03(1 \mathrm{H}, \mathrm{dd}, J$ 8.5, $2.5 \mathrm{~Hz}, \mathrm{H} 10), 7.15(1 \mathrm{H}, \mathrm{dd}, J$ 9.0, $2.5 \mathrm{~Hz}, \mathrm{H} 17), 7.23$ (1H, d, J 2.5 Hz, H12), 7.49 (1H, d, J $2.5 \mathrm{~Hz}, \mathrm{H} 15) .{ }^{13} \mathrm{C}$ NMR (100 MHz, $\mathrm{CDCl}_{3}$ ), 20.4 (OAc), 20.5 (OAc), 20.7 (OAc), 61.4 (C5), 66.8 (C3), 67.52 (C2), 68.5 (C4), 95.9 (C1), 118.4 (C18/C12), 118.5 (C18/C12), 121.8 (C9), 123.5 (C10), 124.8 (ArQ), 127.6 (C17), 128.4 (ArQ), 130.2 (ArQ), 130.6 (C15), 144.2 (ArQ), 147.5 (ArQ), 151.9 (ArQ), 169.4 (OAc), 169.9 (OAc), 170.2 (OAc). IR $v_{\max } / \mathrm{cm}^{-1}$ (oil), 1745 (C=O), $1599(\mathrm{C}=\mathrm{C}), 1495(\mathrm{C}=\mathrm{C}), 1248(\mathrm{C}-\mathrm{O}), 1095$ (CO), $862(\mathrm{C}-\mathrm{H}), 800(\mathrm{C}-\mathrm{H}), 709$ (C-Cl). FTMS (ESI, M+Na) 569.0150 $\mathrm{C}_{23} \mathrm{H}_{21} \mathrm{O}_{9} \mathrm{Cl}_{3} \mathrm{Na}$ req. 569.0143.

\section{General procedure C: Deprotections}

Under argon, the protected sugar (1eq) was dissolved in anhydrous $\mathrm{MeOH}\left(1 \mathrm{ml}\right.$ per mmol). $\mathrm{K}_{2} \mathrm{CO}_{3}(0.1$ eq) was then added. The reaction was then stirred until it was deemed to be complete as evidenced by TLC analysis. Amberlite IR-120 (plus) resin was then added and the reaction was stirred for a further 30 minutes. The resin was then filtered off and the filtrate concentrated in vacuo to yield the desired product.

Synthesis of triclosan- $\beta$-D-galactopyranoside (3a). Following general procedure C: $O$-(2,3,4,6-tetra- $O$ acetyl- $\beta$-D-galactopyranosyl)-5-chloro-2-(2,4-dichlorophenoxy)phenol (2a) (715 mg, $1.15 \mathrm{mmol}$ ) was reacted with potassium carbonate (16 $\mathrm{mg}, 0.115 \mathrm{mmol}$ ) to yield (3a) as an amorphous foam (429 $\mathrm{mg}, 83 \%)$. $[\alpha]_{\mathrm{D}}{ }^{2{ }^{\circ} \mathrm{C}}-28.29(c \mathrm{0.35}, \mathrm{MeOH}) .{ }^{1} \mathrm{H}$ NMR (400 MHz, MeOD), $3.59(1 \mathrm{H}, \mathrm{dd}, J$ 10.0, $3.0 \mathrm{~Hz}, \mathrm{H} 3), 3.66-3.80$ (4H, m, H6', H6, H2, H5), 3.91 (1H, app. d, J 3.0 Hz, H4), 4.98 (1H, d, J 8.0 Hz, H1), 6.85 (1H, d, J 9.0 Hz, H18), 6.87 (1H, d, J 8.5 Hz, H9), 7.02 (1H, dd, J 8.5 Hz, 2.5 Hz, H10), 7.22 (1H, dd, J 9.0, 2.5 Hz, H17), $7.38(1 \mathrm{H}, \mathrm{d}, J 2.5 \mathrm{~Hz}, \mathrm{H} 12), 7.49$ (1H, d, J $2.5 \mathrm{~Hz}, \mathrm{H} 15) .{ }^{13} \mathrm{C}$ NMR (100 MHz, MeOD), 62.3 (C6), 70.1 (C4), 72.1 (C2/5), 74.9 (C3), 77.1 (C2/5), 103.0 (C1), 119.3 (C12), 120.9 (C18), 122.5 (C9), 124.0 (C10), 126.2 (ArQ), 129.4 (C17), 129.62 (ArQ), 131.2 (C15), 131.26 (ArQ), 145.5 (ArQ), 150.6 (ArQ), 153.4 (ArQ). IR $v_{\max } / \mathrm{cm}^{-1}$ (thin film), $3391(\mathrm{OH}), 1652(\mathrm{C}=\mathrm{C}), 1449(\mathrm{C}=\mathrm{C}), 1026(\mathrm{C}-\mathrm{O}), 668(\mathrm{C}-\mathrm{Cl})$. FTMS (ESI, $\mathrm{M}+\mathrm{Na}), 472.9914 \mathrm{C}_{18} \mathrm{H}_{17} \mathrm{O}_{7} \mathrm{Cl}_{3} \mathrm{Na}$, req. 472.9932. 
Synthesis of triclosan- $\beta$-D-glucopyranoside (3b). Following general procedure C: $O$-(2,3,4,6-tetra- $O$ acetyl- $\beta$-D-glucopyranosyl)-5-chloro-2-(2,4-dichlorophenoxy)phenol (2b) ( $500 \mathrm{mg}, 0.81 \mathrm{mmol}$ ) was reacted with potassium carbonate $(11 \mathrm{mg}, 0.081 \mathrm{mmol})$ to yield $(\mathbf{3 b})$ as an amorphous foam $(258 \mathrm{mg}, 71 \%)$. $[\alpha]_{\mathrm{D}}{ }^{2{ }^{\circ} \mathrm{C}}-21(c \mathrm{0.5}, \mathrm{MeOH}) .{ }^{1} \mathrm{H}$ NMR (400 MHz, MeOD), 3.27-3.53 (4H, m, H2, H3, H4, H5), 3.70 (1H, dd, $J$ 12.0, $5.5 \mathrm{~Hz}, \mathrm{H6}$ ), 3.88 (1H, dd, $J$ 12.0, $2.0 \mathrm{~Hz}, \mathrm{H} 6), 5.04$ (1H, d, $J 8.0 \mathrm{~Hz}, \mathrm{H} 1), 6.85$ (1H, d, $J 9.0 \mathrm{~Hz}$, H18), 6.88 (1H, d, J 8.5 Hz, H9), 7.03 (1H, dd, J 8.5, 2.5 Hz, H10), 7.22 (1H, dd, J 9.0, 2.5 Hz, H17), 7.36 $(1 \mathrm{H}, \mathrm{d}, J 2.5 \mathrm{~Hz}, \mathrm{H} 12), 7.49(1 \mathrm{H}, \mathrm{d}, J 2.5 \mathrm{~Hz}, \mathrm{H} 15) .{ }^{13} \mathrm{C} \mathrm{NMR}(100 \mathrm{MHz}, \mathrm{MeOD}), 62.4$ (C6), 71.1 (C2/3/4/5), 74.8 (C2/3/4/5), 78.0 (C2/3/4/5), 78.3 (C2/3/4/5), 102.3 (C1), 119.3 (C12), 120.9 (C18), 122.5 (C9), 124.1 (C10), 126.2 (ArQ), 129.4 (C17), 129.6 (ArQ), 131.2 (C15), 131.3 (ArQ), 145.5 (ArQ), 150.4 (ArQ), 153.4 (ArQ). IR $v_{\max } / \mathrm{cm}^{-1}$ (thin film), $3411(\mathrm{OH}), 1652(\mathrm{C}=\mathrm{C}), 1450(\mathrm{C}=\mathrm{C}), 1031$ (C-O), 758 (C-C). FTMS (ESI, M+Na), $472.9924 \mathrm{C}_{18} \mathrm{H}_{17} \mathrm{O}_{7} \mathrm{Cl}_{3} \mathrm{Na}$, req. 472.9932.

Synthesis of triclosan- $\alpha$-D-arabinopyranoside $(3 \mathbf{c})$. Following general procedure C: $O$ - $(2,3,4$-tri- $O$ acetyl- $\alpha$-D-arabinopyranosyl)-5-chloro-2-(2,4-dichlorophenoxy)phenol (2c) (1.47 g, 2.69 mmol) was reacted with potassium carbonate $(37 \mathrm{mg}, 0.269 \mathrm{mmol})$ to yield $(3 \mathrm{c})$ as an amorphous foam $(1.195 \mathrm{~g}, 99 \%)$. $[\alpha]_{\mathrm{D}}{ }^{20^{\circ} \mathrm{C}}$ +17.6 (c 1.1, MeOH). ${ }^{1} \mathrm{H}$ NMR (400 MHz, MeOD), 3.63 (1H, dd, J 8.5, $\left.3.5 \mathrm{~Hz}, \mathrm{H} 3\right), 3.71$ (1H, dd, J 12.5, 2.0 Hz, H5'), 3.74 (1H, dd, J 8.5, 6.5 Hz, H2), 3.86-3.89 (1H, m, H4), 3.93 (1H, dd, J 12.5, 3.5 Hz, H5), 5.00 $(1 \mathrm{H}, \mathrm{d}, J 6.5 \mathrm{~Hz}, \mathrm{H} 1), 6.84(1 \mathrm{H}, \mathrm{d}, J 9.0 \mathrm{~Hz}, \mathrm{H} 18), 6.92(1 \mathrm{H}, \mathrm{d}, J 8.5 \mathrm{~Hz}, \mathrm{H} 9), 7.06$ (1H, dd, J 8.5, $2.5 \mathrm{~Hz}$, H10), 7.25 (1H, dd, J 9.0, $2.5 \mathrm{~Hz}, \mathrm{H} 17), 7.32(1 \mathrm{H}, \mathrm{d}, J 2.5 \mathrm{~Hz}, \mathrm{H} 12), 7.53$ (1H, d, J 2.5 Hz, H15). ${ }^{13} \mathrm{C}$ NMR (100 MHz, MeOD), 66.8 (C5), 69.1 (C4), 72.0 (C2), 73.9 (C3), 102.7 (C1), 119.5 (C12), 120.6 (C18), 122.6 (C9), 124.1 (C10), 126.3 (ArQ), 129.3 (C17), 129.8 (ArQ), 131.2 (C15), 145.7 (ArQ), 150.2 (ArQ), 153.3 (ArQ). IR $v_{\max } / \mathrm{cm}^{-1}$ (solid), 3359 (O-H), 1595 (C=C), 1471 (C=C), 1223 (C-C), 1067 (C-C), 1011 (C-C), 906 (C-H), 778 (C-Cl). FTMS (ESI, M+Na) $442.9824 \mathrm{C}_{17} \mathrm{H}_{15} \mathrm{O}_{6} \mathrm{Cl}_{3} \mathrm{Na}$, req. 442.9826.

Synthesis of triclosan- $\alpha$-D-galactopyranoside (3d). Following general procedure C: $O$-(2,3,4,6-tetra- $O$ acetyl- $\alpha$-D-galactopyranosyl)-5-chloro-2-(2,4-dichlorophenoxy)phenol (2d) (432 mg, $0.7 \mathrm{mmol}$ ) was reacted with potassium carbonate $(10 \mathrm{mg}, 7 \times 10-5 \mathrm{~mol})$ to yield (3d) as an orange oil $(166 \mathrm{mg}, 37 \%)$. $[\alpha]_{\mathrm{D}}{ }^{20^{\circ} \mathrm{C}}$ +88.6 (c 1.3, MeOH). ${ }^{1} \mathrm{H}$ NMR (400 MHz, MeOD), 3.56 (1H, dd, J 10.0, 3.5 Hz, H3), 3.65-3.66 (2H, m, H6', H6), 3.74-3.78 (1H, m, H5), 3.85 (1H, dd, J 3.5, 1.5 Hz, H4), 3.92 (1H, dd, J 10.0, 3.5 Hz, H2), 5.34 $(1 \mathrm{H}, \mathrm{d}, J 3.5 \mathrm{~Hz}, \mathrm{H} 1), 3.92(1 \mathrm{H}, \mathrm{d}, J 9.0 \mathrm{~Hz}, \mathrm{H} 18), 7.01$ (1H, d, J 8.5 Hz, H9), 7.07 (1H, dd, J 8.5, $2.5 \mathrm{~Hz}$, H10), 7.23 (1H, dd, J 8.5, $2.5 \mathrm{~Hz}, \mathrm{H} 12), 7.43(1 \mathrm{H}, \mathrm{d}, J 2.5 \mathrm{~Hz}, \mathrm{H} 12), 7.53$ (1H, d, J 2.5 Hz, H15). ${ }^{13} \mathrm{C}$ NMR (100 MHz, MeOD), 62.4 (C6), 69.7 (C2), 70.7 (C4), 71.2 (C3), 73.8 (C5), 100.0 (C1), 119.4 (C12), 119.8 (C18), 123.3 (C9/C10), 124.0 (C9/C10), 125.6 (ArQ), 129.3 (C17), 131.3 (C15), 131.7 (ArQ), 145.4 (ArQ), 150.0 (ArQ x 2), 153.8 (ArQ). IR $v_{\max } / \mathrm{cm}^{-1}$ (solid), $3358(\mathrm{O}-\mathrm{H}), 2935(\mathrm{C}-\mathrm{H}), 1569$ (C=C), 1491 (C=C), 1259 (C-C), 1073 (C-C), 949 (C-C), 866 (C-H), 754 (C-Cl). FTMS (ESI, M+Na) $472.9930 \mathrm{C}_{18} \mathrm{H}_{17} \mathrm{O}_{7} \mathrm{Cl}_{3} \mathrm{Na}$, req. 472.9932. 
Synthesis of triclosan- $\alpha$-D-glucopyranoside (3e). Following general procedure C: $O$-(2,3,4,6-tetra- $O$ acetyl- $\alpha$-D-glucopyranosyl)-5-chloro-2-(2,4-dichlorophenoxy)phenol (2e) (345 $\mathrm{mg}, 0.56 \mathrm{mmol}$ ) was reacted

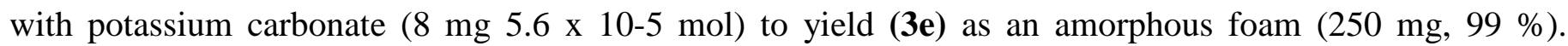
$[\alpha]_{\mathrm{D}}{ }^{2{ }^{\circ} \mathrm{C}}+7.9\left(c\right.$ 12.5, MeOH). ${ }^{1} \mathrm{H}$ NMR (400 MHz, MeOD), $3.44(1 \mathrm{H}, \mathrm{dd}, J 10.5,8.5 \mathrm{~Hz}, \mathrm{H} 3 / \mathrm{H} 4), 3.56-3.72$ (5H, m, H6', H6, H2/H3/H4/H5), 5.59 (1H, d, J 3.0 Hz, H1), 6.83 (1H, d, J 9.0 Hz, H18), 6.94 (1H, d, J 8.5 Hz, H9), 7.05 (1H, dd, J 8.5, $2.5 \mathrm{~Hz}, \mathrm{H} 10), 7.23$ (1H, dd, J 9.0, $2.5 \mathrm{~Hz}, \mathrm{H} 17), 7.44$ (1H, d, J $2.5 \mathrm{~Hz}, \mathrm{H} 12)$, 7.50 (1H, d, J 2.5, H15). ${ }^{13} \mathrm{C}$ NMR (100, MeOD), 62.1 (C6), 70.9 (C2/C3/C4/C5), 73.1 (C2/C3/C4/C5), 74.7 (C2/C3/C4/C5), 75.0 (C2/C3/C4/C5), 100.4 (C1), 119.8 (C12), 120.2 (C18), 122.8 (C9), 124.8 (C10), 125.9 (ArQ), 129.4 (C17), 131.3 (C15), 131.4 (ArQ), 145.8 (ArQ), 150.2 (ArQ), 153.5 (ArQ). IR $v_{\max } / \mathrm{cm}^{-1}$ (solid), 3356 (O-H), 2938 (C-H), 1569 (C=C), 1471 (C=C), 1224 (C-C), 1056 (C-C), 863 (C-H), 783 (C-Cl). FTMS (ESI, M+Na) $472.9929 \mathrm{C}_{18} \mathrm{H}_{17} \mathrm{O}_{7} \mathrm{Cl}_{3} \mathrm{Na}$, req.472.9932.

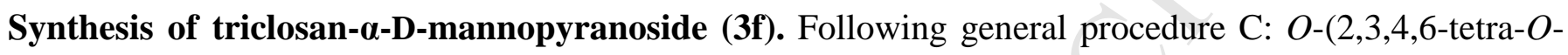
acetyl- $\alpha$-D-mannopyranosyl)-5-chloro-2-(2,4-dichlorophenoxy)phenol (2f) (381 $\mathrm{mg}, 0.6 \mathrm{mmol}$ ) was reacted with potassium carbonate $(8.5 \mathrm{mg}, 0.06 \mathrm{mmol})$ to yield $(\mathbf{3 f})$ as an amorphous foam $(246 \mathrm{mg}, 89 \%) .[\alpha]_{\mathrm{D}}{ }^{20^{\circ} \mathrm{C}}$ +41.9 (c 0.82, MeOH). ${ }^{1} \mathrm{H}$ NMR (400 MHz, MeOD), 3.46-3.76 (6H, m, H2, H3, H4, H5, H6, H6'), 5.45 $(1 \mathrm{H}, \mathrm{d}, J 1.5 \mathrm{~Hz}, \mathrm{H} 1), 6.75$ (1H, d, J 9.0 Hz, H18), 7.06-707 (2H, m, H9, H10), 7.21 (1H, dd, J 9.0, 2.5 Hz, H17), 7.48 (1H, d, J $2.5 \mathrm{~Hz}, \mathrm{H} 12), 7.51(1 \mathrm{H}, \mathrm{d}, J 2.5 \mathrm{~Hz}, \mathrm{H} 15) .{ }^{13} \mathrm{C}$ NMR (100 MHz, MeOD), 62.5 (C6), 68.0 (C2/C3/C4/C5), 71.6 (C2/C3/C4/C5), 72.2 (C2/C3/C4/C5), 75.8 (C2/C3/C4/C5), 101.2 (C1), 119.2 (C18), 119.5 (C12), 123.6 (C10/C9), 124.2 (C10/9), 125.4 (ArQ), 129.3 (ArQ), 129.3 (C17), 131.3 (C15), 131.8 (ArQ), 145.0 (ArQ), 149.8 (ArQ), 153.9 (ArQ). IR v $v_{\max } / \mathrm{cm}^{-1}$ (solid), 3325 (O-H), 2933 (C-H), 1597 $(\mathrm{C}=\mathrm{C}), 1490(\mathrm{C}=\mathrm{C}) 1258$ (C-O), 1098 (C-C), 1000 (C-C), 751 (C-Cl). FTMS (ESI, M+Na) 472.9930 $\mathrm{C}_{18} \mathrm{H}_{17} \mathrm{O}_{7} \mathrm{Cl}_{3} \mathrm{Na}$, req.472.9932.

Synthesis of triclosan- $\beta$-D-arabinopyranoside $(\mathbf{3 g})$. Following general procedure C: $O$ - $(2,3,4$-tri- $O$ acetyl- $\beta$-D-arabinopyranosyl)-5-chloro-2-(2,4-dichlorophenoxy)phenol (2g) (3.5g, $6.4 \mathrm{mmol})$ was reacted with potassium carbonate $(88 \mathrm{mg}, 0.64 \mathrm{mmol})$ to yield $(\mathbf{3 g})$ as an amorphous foam $(2.37 \mathrm{~g}, 88 \%)$. $[\alpha]_{\mathrm{D}}{ }^{20^{\circ} \mathrm{C}}$ 56.4 (c 0.85, MeOH). ${ }^{1} \mathrm{H} \mathrm{NMR}$ (400 MHz, MeOD), 3.61 (1H, dd, $J$ 12.5, $2.0 \mathrm{~Hz}, \mathrm{H} 5$ '), 3.63 (1H, dd, $J$ 10.0, $3.5 \mathrm{~Hz}, \mathrm{H} 3), 3.76$ (1H, dd, $J$ 12.5, $1.0 \mathrm{~Hz}, \mathrm{H} 5), 3.81-3.82(1 \mathrm{H}, \mathrm{m}, \mathrm{H} 4), 3.95$ (1H, dd, $J 10.0,3.5 \mathrm{~Hz}, \mathrm{H} 2)$, $5.64(1 \mathrm{H}, \mathrm{d}, J 3.5 \mathrm{~Hz}, \mathrm{H} 1), 6.78$ (1H, d, J 9.0 Hz, H18), 6.99 (1H, d, J 8.5 Hz, H9), 7.05 (1H, dd, J 8.5, 2.5 $\mathrm{Hz}, \mathrm{H} 10), 7.20(1 \mathrm{H}$, dd, J 9.0, $2.5 \mathrm{~Hz}, \mathrm{H} 17), 7.35(1 \mathrm{H}, \mathrm{d}, J 2.5 \mathrm{~Hz}, \mathrm{H} 12), 7.50(1 \mathrm{H}, \mathrm{d}, J 2.5 \mathrm{~Hz}, \mathrm{H} 15) .{ }^{13} \mathrm{C}$ NMR (100 MHz, MeOD), 65.6 (C5), 69.7 (c2), 70.5 (C4), 70.6 (C3), 100.6 (C1), 119.5 (C12), 119.8 (C18), 123.4 (C9), 124.1 (C10), 125.6 (ArQ), 129.3 (C17), 129.5 (ArQ), 131.3 (C15), 131.7 (ArQ), 145.5 (ArQ), 150.0 (ArQ), 153.7 (ArQ). IR $v_{\max } / \mathrm{cm}^{-1}$ (solid), 3360 (O-H), 2931 (C-H), 1596 (C=C), 1224 (C-O), 1076 (CC), 999 (C-C), 756 (C-Cl). FTMS (ESI, M+Na) $442.9824 \mathrm{C}_{17} \mathrm{H}_{15} \mathrm{O}_{6} \mathrm{Cl}_{3} \mathrm{Na}$, req.442.9826.

Bacterial strains. All strains were from the American Type Culture Collection (ATCC University Boulevard, Manassas, VA, USA) except as indicated NCTC (National Collection of Type Cultues, Public 
Health England, Porton Down, Salisbury, UK), OCC (Oxoid Culture Collection (Thermofisher Scientific, Wade Road, Basingstoke, UK). Gram negative: Aeromonas hydrophila OCC 778, Citrobacter freundii 8090, OCC 851, Enterobacter aerogenes 13048, Enterobacter cloacae 13047, Cronobacter sakazakii 29544, Escherichia coli 8739, 10536, 11775, 25922, 35218, 700728, NCTC 13216, OCC 122, Escherichia hermanii 33650, Hafnia alvei 13337, Klebsiella aerogenes NCTC 8167, Klebsiella pneumoniae 10031, 13883, Proteus mirabilis 12453, Proteus vulgaris OCC 195, Pseudomonas aeruginosa 27853, Salmonella enterica subspecies enterica serotypes: Abony NCTC 6017, Arizonae OCC 706, Dublin OCC 627, Enteritidis 13076, Indiana OCC 597, Infantis OCC 2133, Nottingham NCTC 7832, Poona NCTC 4840, Pullorum OCC 273, Typhimurium 14028 and Virchow NCTC 5742, Serratia marcescens OCC 217. Gram positive: Bacillus cereus 14579, Bacillus subtilis NCTC 10073, Enterococcus faecalis 29212, 33186, Enterococcus faecium 19434, Staphylococcus aureus 6538, 6538P, 9144, 25923, 29213, NCTC 13758, OCC 104, OCC 106, Staphylococcus epidermidis 155, 12228, 14990, Staphylococcus haemolyticus OCC 2223, Staphylococcus saprophyticus 15305, Streptococcus agalactiae OCC 182, Streptococcus pneumoniae 6305, 49619, Streptococcus pyogenes 19615, Streptococcus viridans OCC 234.

MIC determination in broth growth medium. Triclosan and its glycosides were dissolved in ethanol then amounts of these stock solutions diluted in Nutrient Broth (NB2; "Oxoid", ThermoFisher, Basingstoke, UK) to give concentrations of $0.01 \mu \mathrm{g} / \mathrm{ml}$ to $128 \mu \mathrm{g} / \mathrm{ml}$ for triclosan and $0.25 \mu \mathrm{g} / \mathrm{ml}$ to $256 \mu \mathrm{g} / \mathrm{ml}$ for its glycosides. Volumes $(180 \mu \mathrm{l})$ were then added to wells of microtitre plates. Bacteria were grown overnight at $37^{\circ} \mathrm{C}$ in NB2 from plate inoculum. Cultures were diluted 1 in $10^{4}$ in saline and $20 \mu$ amounts added to the triclosan/ triclosan glycoside solutions. Once filled, plates were covered, placed in a Bioscreen C MBR instrument (Oy Growth Curves Ab Ltd. Helsinki, Finland), incubated at $37^{\circ} \mathrm{C}$ and optical density (OD) of each well measured every 15 minutes after agitation. The minimum inhibitory concentration (MIC) of a compound was defined as the lowest concentration of inhibitor that was required to eliminate an increase in OD after 18 hours incubation at $37^{\circ} \mathrm{C}$.

MIC determination on agar plates. Amounts of triclosan glycoside solutions prepared as described above were added to Nutrient Agar (NA2; "Oxoid", ThermoFisher) and the media autoclaved for 15 minutes at $121^{\circ} \mathrm{C}$. Plates were poured, dried and stored at $4^{\circ} \mathrm{C}$ using within one week of pouring. Cultures were prepared as above, diluted 1 in $10^{2}$ in saline and inoculated onto plates using an "Oxoid" replicator system.

\section{References}

1. Docquier, J-D., and S. Mangani. 2018. An update on $\beta$-lactamase discovery and development. Drug Res. Updates. 36: 13-29.

2. WHO. 2016. Tackling drug-resistant infections globally: final report and recommendations.

3. WHO. 2017. Antibacterial Agents in Clinical Development. An analysis of the antibacterial clinical development pipeline, including tuberculosis. WHO/EMP/IAU/2017.12. 
4. Bhargava, H. N., and P.A. Leonard. 1996. Triclosan: applications and safety. Am. J. Infect. Control. 24:209-218.

5. Regos, J., and H.R. Hitz. 1974. Investigations on the model of action of triclosan, a broad spectrum antibacterial agent. Zbl. Bakt-Int. J. Med. M. 226:390-401.

6. Regos, J., O. Zak, R. Solf, W.A. Vischer, and E.G. Weirich. 1979. Antimicrobial Spectrum of Triclosan, a Broad-Spectrum Antimicrobial Agent for Topical Application. Dermatologica. 158:72-79.

7. Russell, A.D. 2002. Mechanisms of antimicrobial action of antiseptics and disinfectants: an increasingly important area of investigation. J. Antimicrob. Chemother. 49:597-599.

8. Schweizer, H.P. 2001. Triclosan: a widely used biocide and its link to antibiotics. FEMS Microbiol. Lett. 202:1-7.

9. Slater-Radosti, C., G. Van Aller, R. Greenwood, R. Nicholas, P.M. Keller, W.E. DeWolf, F. Fan, D.J. Payne, and D.D. Jaworski. 2001. Biochemical and genetic characterization of the action of triclosan on Staphylococcus aureus. J. Antimicrob. Chemother. 48:1-6.

10. Escalada, M.G., J.L. Harwood, J.Y. Maillard, and D. Ochs. 2005. Triclosan inhibition of fatty acid synthesis and its effect on growth of E. coli and Ps. aeruginosa. J. Antimicrob. Chemother. 55:879-882.

11. Heath, R.J., N. Su, C.K. Murphy, and C.O. Rock. 2000. The enoyl-[acyl-carrier-protein] reductases FabI and FabL from Bacillus subtilis. J. Biol. Chem. 275:40128-40133.

12. Hoang, T.T., and H.P. Schweizer. 1999. Characterization of Pseudomonas aeruginosa enoyl-acyl carrier protein reductase: a target for the antimicrobial triclosan and its role in acylated homoserine lactone synthesis. J. Bacteriol. 181:5489-5497.

13. McMurry, L. M., M. Oethinger, and S.B. Levy. 1998. Triclosan Targets Lipid Synthesis. Nature. 394:531-532.

14. Heath, R. J., Y.T. Yu, M.A. Shapiro, E. Olson, and C.O. Rock. 1998. Broad spectrum antimicrobial biocides target the FABI component of fatty acid biosynthesis. J. Biol. Chem. 273:30316-30320.

15. Xu, H., T.J. Sullivan, J.I. Sekiguchi, T. Kirikae, I. Ojima, C.F. Stratton, W.M. Mao, F.L. Rock, M.R.K. Alley, F. Johnson, S.G. Walker, and P.J. Tonge. 2008. Mechanism and Inhibition of saFabI, the Enoyl Reductase from Staphylococcus aureus. Biochem. 47:4228-4236.

16. Zhang, Y.M., S.W. White and C.O. Rock. 2006. Inhibiting bacterial fatty acid synthesis. J. Biol. Chem. 281:17541-17544.

17. a) Milner, S.J.; Carrick, C.T.; Kerr, K.G.; Snelling, A.M.; Thomas, G.H.; Duhme-Klair, A.K.; Routledge, A. 2014. Probing bacterial uptake of glycosylated ciprofloxacin conjugates. Chembiochem. 15: 466-471; b) Jung, M.E.; Yang, E.C.; Vu, B.T.; Kiankarimi, M.; Spyrou, E.; Kaunitz, J. 1999. Glycosylation of fluoroquinolones through directed and oxygenated polymethylene linkages as a sugarmediated active transport system for antimicrobials J. Med. Chem. 42: 3899-3909; c) Conners, S.B.; Montero, C.I.; Comfort, D.A. ; Shockley, K.R.; Johnson, M.R.; Chhabra, S.R.; Kelly, R.M. 2005. An expression-driven approach to the prediction of carbohydrate transport and utilization regulons in the hyperthermophilic bacterium Thermotoga maritima. J. Bacteriol. 187: 7267-7282; d) Barrangou, 
R.; Azcarate-Peril, M.A.; Duong, T.; Conners, S.B.; Kelly, R.M.; Klaenhammer, T.R. 2006. Global analysis of carbohydrate utilization by Lactobacillus acidophilus using cDNA microarrays. Proc. Natl. Acad. Sci. 103: 3816-3821; e) Bovill, R.; Evans, P.G.; Howse, G.L.; Osborn, H.M.I. 2016. Synthesis and biological analysis of novel glycoside derivatives of L-AEP, as targeted antibacterial agents. Bioorg. Med. Chem. Lett. 26:3774-3779.

18. a) Cellier, M.; Fazackerley, E.; James, A.L.; Orenga, S.; Perry, J.D.; Turnbull, G.; Stanforth, S.P. 2014. Synthesis of 2-arylbenzothiazole derivatives and their application in bacterial detection. Bioorg. Med. Chem. 22: 1250-1261; b) Orenga, S.; James, A.L.; Manafi, M.; Perry, J.D.; Pincus, D.H. 2009. Enzymatic substrates in microbiology. J. Microbiol. Methods 79: 139-155; c) Perry, J.D.; Morris, K.A.; James A.L.; Oliver, M.; Gould, F.K. 2007. Evaluation of novel chromogenic substrates for the detection of bacterial beta-glucosidase. J. Appl. Microbiol. 102: 410-415; d) Chilvers, K.F.; Perry, J.D.; James, A.L.; Reed, R.H. 2001. Synthesis and evaluation of novel fluorogenic substrates for the detection of bacterial beta-galactosidase J. Appl. Microbiol. 91: 1118-1130.

19. Fernandez, C.; Nieto, O.; Fontenla, J.A.; Rivas, R.; de Ceballos, M.L.; Fernandez-Mayoralas, A. 2003. Synthesis of glycosyl derivatives as dopamine prodrugs:interaction with glucose carrier GLUT-1. Org. Biom. Chem. 1: 767-771.

20. Kämpfer, P., O. Rauhoff, and W. Dott. 1991. Glycosidase Profiles of Members of the Family Enterobacteriaceae, J. Clin. Microbiol. 29:2877-2879.

21. Manafi, M., W. Kneifel, and S. Bascomb. 1991. Fluorogenic and Chromogenic Substrates Used in Bacterial Diagnostics. Microbiol. Rev. 55:335-348.

22. Orenga, S., A.L. James, M. Manafi, J.D. Perry, and D.H. Pincus. 2009. Enzymatic substrates in microbiology. J. Microbiol. Meth. 79:139-155.

23. Perry, J. D., and A.M. Freydiere. 2007. The application of chromogenic media in clinical microbiology. J. Appl. Microbiol. 103:2046-2055.

24. Bascomb, S., and M. Manafi, M. 1998. Use of enzyme tests in characterization and identification of aerobic and facultatively anaerobic gram-positive cocci. Clin. Microbiol. Rev. 11:318-30.

25. Bovill, R.A., and G. Howse. 2018. Triclosan derivatives and uses thereof. US9,908,912B2.

26. Choo, E. J. and Chambers, Henry F. 2016. Treatment of Methicillin-Resistant Staphylococcus aureus Bacteremia. Infection \& Chemotherapy. 48: 267-273.

27. Schentag JJ, Hyatt JM, Carr JR, Paladino JA, Birmingham MC, Zimmer GS, Cumbo TJ. 1998. Genesis of methicillin-resistant Staphylococcus aureus (MRSA), how treatment of MRSA infections has selected for vancomycin-resistant Enterococcus faecium, and the importance of antibiotic management and infection control. Clin. Infect. Dis. 26: 1204-14.

28. Keith A. Rodvold, K.A. and K. W. McConeghy. 2014 Methicillin resistant Staphylococcus aureus Therapy: Past, Present, and Future. Clin. Infect. Dis. 58:S20-S27. 
29. K. Hiramatsu, Y. Katayama, M. Matsuo, T. Sasaki, Y. Morimoto, A. Sekiguchi, and T. Baba. 2014. Multi-drug-resistant Staphylococcus aureus and future chemotherapy. J Infect. Chemother. 20:593-601.

30. Otto, M., B.N. Kreisworth, and H.F. Chambers. 2010. Community-associated methicillinresistant Staphylococcus aureus. Lancet. 375:1557-1568.

31. Hartman, B.J. and A. Tomasz. 1984. Low-affinity penicillin-binding protein associated with $\beta$ lactam resistance in Staphylococcus aureus J. Bacteriol. 158:513-516.

32. Baek, K. T., A. Gründling, R.G. Mogensen, L. Thøgersen, A. Petersen, W. Paulander and D. Frees. 2014. $\beta$-Lactam resistance in methicillin-resistant Staphylococcus aureus USA300 is increased by inactivation of the ClpXP Protease. Antimicrob. Agent. Chemother. 58:4593-4603.

33. ChemBiodraw 14.0 PerkinElmer

34. Hunter, C.J., M. Petrosyan, H.R. Ford, N.V. Prasadarao. 2008. Enterobacter sakazakii: An Emerging Pathogen in Infants and Neonates. Surg. Infect. 9:533-539.

35. Yan, Q.Q., O. Condell, K. Power, F. Butler, B.D. Tall, and S. Fanning. 2012. Cronobacter species (formerly known as Enterobacter sakazakii) in powdered infant formula: a review of our current understanding of the biology of this bacterium: A review of Cronobacter species. J. Appl. Microbiol. 113:1-15.

36. Kotiranta, A., K. Lounatmaa, and M. Haapasalo. 2000. Epidemiology and pathogenesis of Bacillus cereus infections. Microbes Infect. 2:189-98.

37. Holbrook R. and J.M. Anderson. 1980. An improved selective and diagnostic medium for the isolation of enumeration of Bacillus cereus in foods. Can. J. Microbiol., 26:753-759. 


\section{Synthesis and Antibacterial profiles of Targeted Triclosan Derivatives}

Gemma L. Howse, ${ }^{a}$ Richard A. Bovill, ${ }^{\mathrm{b}}$ Peter J. Stephens, ${ }^{\mathrm{b}}$ Helen M. I. Osborn $^{\text {a\# }}$

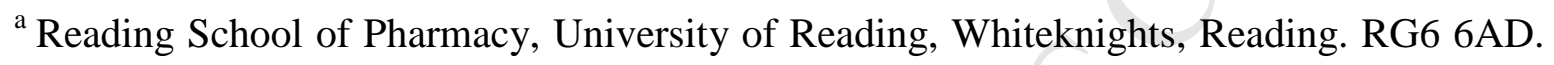
$\mathrm{UK}$

${ }^{\mathrm{b}}$ ThermoFisher Scientific, Wade Road, Basingstoke, Hampshire. RG24 8PW. UK

\# To whom correspondence should be addressed. Richard Bovill :

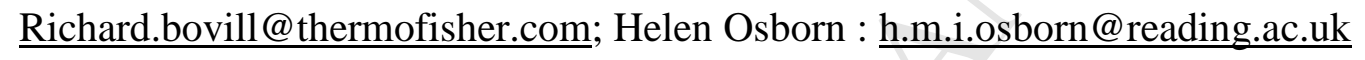

Highlights

- Synthesis and characterisation of four $\alpha$-D-glycopyranosides and three $\beta$-Dglycopyranosides of the broad antibacterial agent triclosan, in generally very good synthetic yields, and with excellent purities

- All of the triclosan glycosides that were synthesized demonstrated antibacterial activity against many of the organisms that were examined.

- $\quad \beta$-Galactoside (3a) and $\alpha$-arabinoside (3c) had MIC values of $0.5 \mu \mathrm{g} / \mathrm{ml}$ for several strains of $S$. aureus and S. haemolyticus.

- Two Bacillus strains could be identified from various strains of Bacillus and Staphylococcus after inoculation onto Nutrient Agar No. 2 with $0.25 \mu \mathrm{g} / \mathrm{ml}$ triclosan$\alpha$-D-glucopyranoside (3e) 